HOW TO STUDY LITERATURE

General Editors: John Peck and Martin Coyle

HOW TO STUDY AN E. M. FORSTER NOVEL 
IN THE SAME SERIES

How to Study a Novel John Peck

Literary Terms and Criticism John Peck and Martin Coyle

How to Study a Shakespeare Play John Peck and Martin Coyle

How to Begin Studying Literature Nicholas Marsh

How to Study a Jane Austen Novel Vivien Jones

How to Study a Thomas Hardy Novel John Peck

How to Study a D. H. Lawrence Novel Nigel Messenger

How to Study a Charles Dickens Novel Keith Selby

How to Study a Joseph Conrad Novel Brian Spittles

How to Study a Renaissance Play Chris Coles

How to Study Modern Drama Kenneth Pickering

How to Study a Poet John Peck

How to Study Chaucer Rob Pope

How to Study Romantic Poetry Paul O'Flinn

How to Study Modern Poetry Tony Curtis

IN PREPARATION

How to Study a James Joyce Novel Chris Coles 


\section{HOW TO STUDY AN E. M. FORSTER NOVEL}

Nigel Messenger

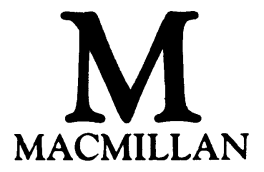


(C) Nigel Messenger 1991

All rights reserved. No reproduction, copy or transmission of this publication may be made without written permission.

No paragraph of this publication may be reproduced, copied or transmitted save with written permission or in accordance with the provision of the Copyright, Designs and Patents Act 1988, or under the terms of any licence permitting limited copying issued by the Copyright Licensing Agency, 33-4 Alfred Place, London WC1E 7DP.

Any person who does any unauthorised act in relation to this publication may be liable to criminal prosecution and civil claims for damages.

First published 1991

Published by

MACMILLAN EDUCATION LTD

Houndmills, Basingstoke, Hampshire RG21 2XS

and London

Companies and representatives

throughout the world

Filmset by Wearside Tradespools, Fulwell, Sunderland

British Library Cataloguing in Publication Data

Messenger, Nigel

How to study an E. M. Forster novel.

1. Fiction in English. Forster, E. M. (Edward Morgan), 1879-1970 - Critical studies

I. Title

823.912

ISBN 978-0-333-49155-3

DOI 10.1007/978-1-349-10851-0 
To

Jenny, Marcus, Timothy and Abigail 


\section{Contents}

General Editors' preface

vii

Acknowledgements

ix

1 Studying Forster: some ideas to get you started

2 The Private Forster: an analysis of Maurice

3 The First Italian Novel: Where Angels Fear to Tread

4 The Second Italian Novel: A Room with a View

5 The First English Novel: The Longest Journey

6 The Second English Novel: Howards End

7 The Indian Novel: A Passage to India

8 Writing a Forster Essay 


\section{$\overline{\text { General Editors' preface }}$}

Everybody who studies literature, either for an examination or simply for pleasure, experiences the same problem: how to understand and respond to the text. As every student of literature knows, it is perfectly possible to read a book over and over again and yet still feel baffled and at a loss as to what to say about it. One answer to this problem, of course, is to accept someone else's view of the text, but how much more rewarding it would be if you could work out your own critical response to any book you choose or are required to study.

The aim of this series is to help you develop your critical skills by offering practical advice about how to read, understand and analyse literature. Each volume provides you with a clear method of study so that you can see how to set about tackling texts on your own. While the authors of each volume approach the problem in a different way, every book in the series attempts to provide you with some broad ideas about the kind of texts you are likely to be studying and some broad ideas about how to think about literature; each volume then shows you how to apply these ideas in a way which should help you construct your own analysis and interpretation. Unlike most critical books, therefore, the books in this series do not simply convey someone else's thinking about a text, but encourage you and show you how to think about a text for yourself.

Each book is written with an awareness that you are likely to be preparing for an examination, and therefore practical advice is given not only on how to understand and analyse literature, but also on how to organise a written response. Our hope is that, although these books are intended to serve a practical purpose, they may also enrich your enjoyment of literature by making you a more confident reader, alert to the interest and pleasure to be derived from literary texts.

John Peck Martin Coyle 


\section{Acknowledgements}

I should like to thank my colleagues in the Humanities Department at Oxford Polytechnic for helping me in so many ways, and past students who have shared their readings of Forster with me. In particular I owe a special debt to Charles Smith at the Computer Centre who patiently instructed me in the skills of word-processing. He has made the writing of this book much less arduous than it would otherwise have been.

I should also like to express my gratitude to the general editors of this series. They have been generous with their encouragement, and have supervised this book at every stage with tactful vigilance. 